\title{
UTILIZATION OF RATS PURUN (ELEOCHALISTS OF DULCIS) AND WATER HYACINTH (EICHHORNIA CRASSIPES) TO REDUCE MERCURY LEVEL (HG) WITH PHYTOREMEDIATION METHOD
}

\author{
* Sileni Putri ${ }^{1}$, Nasoetion ${ }^{2}$, and Muhtadi ${ }^{3}$ \\ ${ }^{1}$ Padang State University, Environmental Science Graduate Student \\ ${ }^{2}$ Lecturer in Environmental Engineering, University of Malahayati \\ ${ }^{3}$ Lecturer in Environmental Engineering, University of Malahayati \\ Email: putrisileni74@gmail.com
}

\begin{abstract}
Metal mercury $(\mathrm{Hg})$, has the chemical name hydragyrum which means liquid. Mercury metal is represented by $\mathrm{Hg}$. In the periodic chemical elements $\mathrm{Hg}$ rank (NA) 80 and have atomic weights (BA 200,59). Rat Purun (Eleocharis dulcis) and water hyacinth (Eichhornia crassipes) are plants that are widely found in tidal swamp land. Both plants can be used as organic fertilizer, biofilter, and absorb toxic elements such as heavy metals Lead $(\mathrm{Pb})$, Iron $(\mathrm{Fe})$, Mercury $(\mathrm{Hg})$, Sulphate (SO4). This study aims to determine the ability of rat purun plants (Eleochalis dulcis) and water hyacinth (Eichhornia crassipes) in reducing mercury $(\mathrm{Hg})$ levels in water and to determine the effectiveness of rat purun plants (Eleochalis dulcis) and water hyacinth (Eichhornia crassipes) in absorbing mercury $\mathrm{Hg}$. Sample analysis was carried out at the Bandar Lampung Standardization Research Center. The results obtained by rat purun plants (Eleochalis dulcis) can reduce mercury levels $(\mathrm{Hg})$. The effectiveness of reducing heavy metal mercury $(\mathrm{Hg})$ is $97.88 \%$. Water hyacinth plants (Eichhornia crassipes) have effectiveness in reducing heavy metals mercury $(\mathrm{Hg})$ which is equal to $96.66 \%$.
\end{abstract}

Keywords: Rat Purun (Eleochalis dulcis) and Water Hyacinth (Eichhornia crassipes), Phytoremediation, Mercury (Hg).

\section{INTRODUCTION}

In Indonesia, development in the industrial sector continues to increase in line with the advancement of science and technology. Human activities in managing and processing the environment play a very important role in the sustainability of 


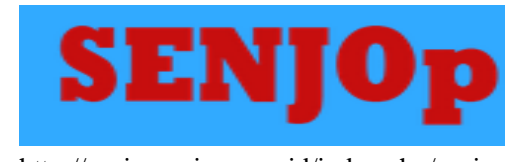

http://senjop.ppj.unp.ac.id/index.php/senjop
Science and Environmental Journals for Postgraduate

Vol. 2 No. 1 (pp. 1-11) December 2019

p_ISSN 2655-5085

e_ISSN 2655-5239

development. With the increase in development will be able to improve the quality of human life and community income. But on the other hand development can reduce environmental quality and community health status due to pollution.

In Law No. 32 of 2009 concerning Environmental Protection and Management, environmental pollution is defined as: Environmental pollution is the entry or inclusion of living things, substances, energy, and /or other components into the environment by human activities so as to exceed the environmental quality standards that have been set. Likewise, the aquatic environment will be exposed to the effects of pollution from industrial processes from human activities in exploiting the environment, so that water will become polluted and cannot be used again by humans for their living needs.

An environmental order can be polluted or damaged due to many things and the main cause is waste, including chemical waste containing toxic materials such as heavy metals. One type of heavy metal is mercury $(\mathrm{Hg})$ which is widely used by humans to meet needs such as in the mining sector. Where the community uses mercury to separate gold grains from rocks through the amalgam process. The influence of inorganic chemicals such as $\mathrm{Pb}, \mathrm{Cd}, \mathrm{Hg}$ in high levels can cause changes in water quality so that it cannot be used in accordance with its designation, besides causing the death of aquatic biota such as fish, plankton.

Traditional gold mining that is developing today by amalgamation which is the processing of gold minerals using mercury to bind gold, has the potential to cause the impact of pollution on aquatic environments such as rivers and seas. In the technique of operating waste rather than tailings containing mercury, it is immediately discharged into the river without being treated first and can pollute aquatic biota such as fish and other aquatic plants. Furthermore, it will damage the food chain in the aquatic environment. Poisoning events due to contamination by mercury have occurred a lot.

One alternative that can be used to reduce mercury pollution $(\mathrm{Hg})$ is the phytoremediation method (Mardekawati et al, 2012). Phytoremediation is the only method of processing waste that uses plants as an indicator, is easy to do or apply, does not cost much and the plants used are also widely available in nature. One plant that is able to reduce the level of impact of heavy metals on water caused by this gold mining is Rat Purun (Eleocharis dulcis) which is a wild plant that is widely found in tidal swamp 


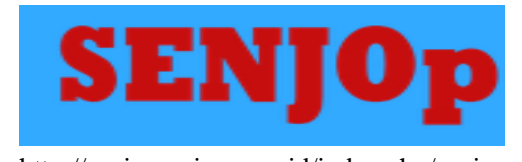

http://senjop.ppj.unp.ac.id/index.php/senjop
Science and Environmental Journals for Postgraduate

Vol. 2 No. 1 (pp. 1-11) December 2019

p_ISSN 2655-5085

e_ISSN 2655-5239

land. Rat Purun (Eleocharis Dulcis) can be used as organic fertilizer, biofilter, and absorb toxic elements such as lead (Pb), iron (Fe) and sulfate (SO4) (Asikin and Thamrin, 2012).

\section{Mercury Heavy Metal (Hg)}

Mercury is very dangerous for health. As a result of Minamata disease in Japan in 1968, more than 1,000 people died, tens of thousands of people suffered from hereditary disability. Minamata gets its name from Minamata City, Kumamoto Prefecture in Japan, which is an area of this disease which began in 1958. At that time there was a problem with epidemics in the Japanese city of Mintamana. Hundreds of people die of strange diseases with symptoms of nerve palsy. Knowing this, health experts find problems that must be immediately observed and sought for causes.

Through in-depth observation of the symptoms of Japanese diseases and habits, including diet, a hypothesis is taken. The hypothesis is that the disease resembles those of heavy metal poisoning. Then from the local culture it is known that Japanese people have the habit of consuming large quantities of marine fish. From the hypothesis and habits of the diet then experiments were conducted to find out whether the fish in the Minamata Bay contain a lot of heavy metals (mercury).

\section{Rat Purun Plants (Eleocharis Dulcis)}

Rat purun (Eleocharis Dulcis) is one of the many wild plants found in acid sulphate tidal swamps. This type of grass has a short rhizome with stolon (an extension of shoots that grows horizontally to the surface of the ground) extending spherical, flat-tipped, brownish to black. Stems erect, unbranched, grayish to shiny green 10-200 cm long and 2-8 $\mathrm{mm}$ thick. The results showed, besides functioning as a plant that traps white rice stalks, rat purun can also be used as organic fertilizer, biofilter, and absorbing toxic elements.

\section{Hyacinth Plants (Eichhornia Crassipes)}

Although water hyacinth (Eichhornia Crassipes) is considered a weed in the waters, it actually plays a role in capturing heavy metal pollutants. A series of studies on the ability of water hyacinth (Eichhornia Crassipes) by Indonesian researchers include (Widyanto and Susilo, 1977 in Aulia, 2013) which reported that within 24 hours water 


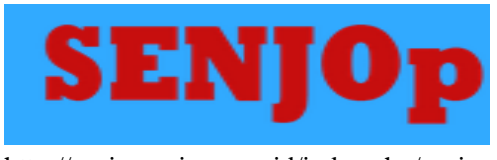

http://senjop.ppj.unp.ac.id/index.php/senjop
Science and Environmental Journals for Postgraduate

Vol. 2 No. 1 (pp. 1-11) December 2019

p ISSN 2655-5085

e_ISSN 2655-5239

hyacinth (Eichhornia crassipes) was able to absorb metal cadmium (Cd), mercury (Hg ), and nickel (Ni), respectively at $1.35 \mathrm{mg} / \mathrm{g}, 1.77 \mathrm{mg} / \mathrm{g}$, and $1.16 \mathrm{mg} / \mathrm{g}$ if the metal does not mix. Water hyacinth (Eichhornia Crassipes) also absorbs Cd $1.23 \mathrm{mg} / \mathrm{g}, \mathrm{Hg} 1.88 \mathrm{mg}$ / g and Ni $0.35 \mathrm{mg} / \mathrm{g}$ dry weight when the metals are mixed with other metals. (Lubis and Sofyan, 1986 in Widodo, 2014) concluded that chrom (Cr) metal can be absorbed by water hyacinth maximally at $\mathrm{pH}$ 7. In its research, the original $\mathrm{Cr}$ metal with a level of 15 ppm decreased to $51.85 \%$.

\section{METHOD}

This type of research is a real type of research. The place for this research was conducted at the Malahayati University, Faculty of Engineering laboratory with artificial waste. Furthermore, sample analysis was carried out in the Bandar Lampung standardization research center laboratory. When this research was conducted in May 2015 until July 2015. Effluents from processing results are analyzed in the laboratory. To find out its efficiency can be calculated by the formula: The reduction efficiency is the ratio of influent and effluent expressed in percent.

$$
\begin{gathered}
\mathrm{E}=\frac{\mathrm{C}_{\mathrm{awal}}-\mathrm{C}_{\mathrm{akhir}}}{\mathrm{C}_{\text {awal }}} \times 100 \% \\
\text { Where }: \\
\mathrm{E}=\text { Efficiency } \\
\mathrm{C}=\text { Concentration }
\end{gathered}
$$

\section{RESULTS AND DISCUSSION}

Rat purun plants (Eleochalis dulcis) and water hyacinth (Elchhornia crassipes) used were taken in swamp areas near rice fields near the study site. In the process of extracting rat purun plants (Eleochalis dulcis) and water hyacinth plants (Elchhornia crassipes) plants are taken whose condition is still good and not deformed (torn, broken). The plant was acclimatized in a tub containing $\mathrm{Hg}$ contaminated liquid waste for 1 week. The rat purun plants (Eleochalis dulcis) which were acclimatized were then selected for plants that were $\pm 15 \mathrm{~cm}$ high, water hyacinth (Elchhornia crassipes) plants which had 


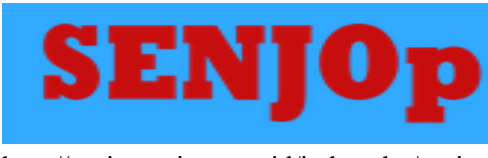

http://senjop.ppj.unp.ac.id/index.php/senjo
Science and Environmental Journals for Postgraduate

Vol. 2 No. 1 (pp. 1-11) December 2019

p ISSN 2655-5085

e_ISSN 2655-5239

been acclimatized and then plants with leaves of 3-6 sheets were selected, plant height was $10-14 \mathrm{~cm}$ with plant conditions still green and has intact roots. Selection is done with good plant characteristics so that the absorption of plants is more optimal for absorbing heavy metals mercury $(\mathrm{Hg})$.

\section{Concentration of Mercury $(\mathrm{Hg})$ in Wastewater}

The concentration of mercury $(\mathrm{Hg})$ in wastewater can be seen in Table 1 .

Table 1 Decreasing Concentration of First-Day Mercury ( $\mathrm{Hg})$ Waste to the End with the Phytoremediation Method

\begin{tabular}{|c|c|c|c|c|c|c|}
\hline No & TPlant & Parameter & Unit & Test Method & $\begin{array}{c}\text { Initial } \\
\text { Concentration }\end{array}$ & $\begin{array}{c}\text { Final } \\
\text { Concentration }\end{array}$ \\
\hline \multirow{4}{*}{1.} & \multicolumn{6}{|c|}{ Rat Purun } \\
\hline & $\mathrm{A}_{1}$ & $(\mathrm{Hg})$ & $\mathrm{mg} / \mathrm{L}$ & AAS & 2.22 & 0.004 \\
\hline & $\mathrm{A}_{2}$ & $(\mathrm{Hg})$ & $\mathrm{mg} / \mathrm{L}$ & AAS & 2.22 & 0.27 \\
\hline & $\mathrm{A}_{3}$ & $(\mathrm{Hg})$ & $\mathrm{mg} / \mathrm{L}$ & AAS & 2.22 & 0.09 \\
\hline \multirow{4}{*}{2.} & \multicolumn{6}{|c|}{ Water hyacinth } \\
\hline & $\mathrm{B}_{1}$ & $(\mathrm{Hg})$ & $\mathrm{mg} / \mathrm{L}$ & AAS & 2.22 & 0.22 \\
\hline & $\mathrm{B}_{2}$ & $(\mathrm{Hg})$ & $\mathrm{mg} / \mathrm{L}$ & AAS & 2.22 & 0.099 \\
\hline & $\mathrm{B}_{3}$ & $(\mathrm{Hg})$ & $\mathrm{mg} / \mathrm{L}$ & AAS & 2.22 & 0.049 \\
\hline \multirow{4}{*}{3.} & \multicolumn{6}{|c|}{\begin{tabular}{|l|} 
No plant \\
\end{tabular}} \\
\hline & $\mathrm{C}_{1}$ & $(\mathrm{Hg})$ & $\mathrm{mg} / \mathrm{L}$ & AAS & 2.22 & 2.22 \\
\hline & $\mathrm{C}_{2}$ & $(\mathrm{Hg})$ & $\mathrm{mg} / \mathrm{L}$ & AAS & 2.22 & 2.22 \\
\hline & $\mathrm{C}_{3}$ & $(\mathrm{Hg})$ & $\mathrm{mg} / \mathrm{L}$ & AAS & 2.22 & 2.22 \\
\hline
\end{tabular}

The average value of decreasing mercury $(\mathrm{Hg})$ in water can be seen from Table 2 .

Table 2 Average Decrease in Mercury $(\mathrm{Hg})$ in Water

\begin{tabular}{|l|l|c|c|}
\hline \multirow{2}{*}{ No. } & \multirow{2}{*}{ Plant } & \multicolumn{2}{|c|}{ Average Concentration } \\
\cline { 3 - 4 } & & Start & End \\
\hline 1. & Rat Purun & $2.22 \mathrm{mg} / \mathrm{L}$ & $0.047 \mathrm{mg} / \mathrm{L}$ \\
\hline 2. & Water hyacinth & $2.22 \mathrm{mg} / \mathrm{L}$ & $0.074 \mathrm{mg} / \mathrm{L}$ \\
\hline 3. & No plant & $2.22 \mathrm{mg} / \mathrm{L}$ & $2.22 \mathrm{mg} / \mathrm{L}$ \\
\hline
\end{tabular}

Source : Primer Data

\section{Rat Purun Plants}

$$
\begin{aligned}
\text { Rata-rata } & =\frac{\mathrm{A}_{1}+\mathrm{A}_{3}}{2} \\
& =\frac{0.004 \mathrm{mg} / \mathrm{L}+0.09 \mathrm{mg} / \mathrm{L}}{2}=0.047 \mathrm{mg} / \mathrm{L}
\end{aligned}
$$

Average decrease: 0.047 


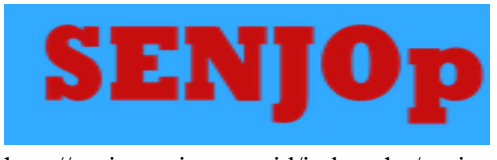

http://senjop.ppj.unp.ac.id/index.php/senjop
Science and Environmental Journals for Postgraduate

Vol. 2 No. 1 (pp. 1-11) December 2019

p_ISSN 2655-5085

e_ISSN 2655-5239

In calculating the average value, there may be data that does not participate calculated like A2 data. A2 repetition data, having values far from A1 and A3 values, are eliminated for calculations. Table 2 shows a significant difference in concentration $(\mathrm{Hg})$ between day 0 and day 15 . Decreased mercury content in wastewater due to the absorption of heavy metals mercury $(\mathrm{Hg})$ by rat purun roots and water hyacinth plants. This is supported by (Tommy and Palapa, 2009), which states that aquatic plants such as water spinach (I. aquatica), lotus (N. nelumbo) and water hyacinth (E. crassipes) which are used for phytoremediation have a significant effect on decreasing $\mathrm{Hg}$ in wastewater contaminated with mercury $(\mathrm{Hg})$.

From Table 2, the efficiency of decreasing mercury $(\mathrm{Hg})$ in wastewater contaminated with mercury $(\mathrm{Hg})$ can be calculated. The efficiency of decreasing mercury $(\mathrm{Hg})$ is presented in Table 3

Table 3 Efficiency in Decreasing Mercury Waste $(\mathrm{Hg})$

\begin{tabular}{|l|l|c|}
\hline No. & \multicolumn{1}{|c|}{ Plants } & Eficiency (\%) \\
\hline 1. & Rat Purun & $97.88 \%$ \\
\hline 2. & Water hyacinth & $96.66 \%$ \\
\hline 3. & No Plant & $0 \%$ \\
\hline
\end{tabular}

Sumber : Data Primer

Ex:

$$
\text { Eff }=\frac{C_{\text {awal }}-C_{\text {akhir }}}{C_{\text {awal }}} \times 100 \%
$$

Rat Purun

$$
\begin{aligned}
\text { Eff } & =\frac{2.22-0.047}{2.22} \times 100 \% \\
& =97.88 \%
\end{aligned}
$$

Table 3 above can be seen that rat purun plants (Eleochalis Dulcis) have the ability to absorb mercury heavy metals by $97.88 \%$ higher compared to water hyacinth plants (Elchhornia Crassipes) with absorption effectiveness of 96.66\%. According to Agustina (2004) rat purun roots (Eleochalis Dulcis) have a large root cavity (cortex) which causes the absorption process to be faster. The absorption of ions in the roots is active where ions 
enter from the epidermis and are then transported to the cytoplasm or cells of the root tissue through the epidermis into the keprotoplasma between root tissue cells namely cortex, endodermis, perisicles and xylem. Concentration of Mercury $(\mathrm{Hg})$ Waste in Plants The concentration of waste mercury $(\mathrm{Hg})$ absorbed by plants using the phytoremediation method can be seen in the table below:

Table 4. Concentration of Mercury (Hg) Waste in Plants.

\begin{tabular}{|c|c|c|c|c|c|c|}
\hline No & Plant & Parameter & Unit & \begin{tabular}{|c|} 
Test \\
Method
\end{tabular} & $\begin{array}{c}\text { Initial } \\
\text { Concetration }\end{array}$ & $\begin{array}{c}\text { Final } \\
\text { Concetration }\end{array}$ \\
\hline \multirow{4}{*}{1.} & \multicolumn{5}{|c|}{ Rat Purun } & \\
\hline & $\mathrm{A}_{1}$ & $(\mathrm{Hg})$ & $\mathrm{mg} / \mathrm{L}$ & AAS & 0 & 2.216 \\
\hline & $\mathrm{A}_{2}$ & $(\mathrm{Hg})$ & $\mathrm{mg} / \mathrm{L}$ & AAS & 0 & 1.950 \\
\hline & $\mathrm{A}_{3}$ & $(\mathrm{Hg})$ & $\mathrm{mg} / \mathrm{L}$ & AAS & 0 & 2.130 \\
\hline \multirow{4}{*}{2.} & \multicolumn{5}{|c|}{ Water hyacinth } & \\
\hline & $\mathrm{B}_{1}$ & $(\mathrm{Hg})$ & $\mathrm{mg} / \mathrm{L}$ & AAS & 0 & 1.999 \\
\hline & $\mathrm{B}_{2}$ & $(\mathrm{Hg})$ & $\mathrm{mg} / \mathrm{L}$ & AAS & 0 & 2.121 \\
\hline & $\mathrm{B}_{3}$ & $(\mathrm{Hg})$ & $\mathrm{mg} / \mathrm{L}$ & AAS & 0 & 2.171 \\
\hline \multirow{4}{*}{3.} & \multicolumn{6}{|c|}{ No Plant } \\
\hline & $\mathrm{C}_{1}$ & $(\mathrm{Hg})$ & $\mathrm{mg} / \mathrm{L}$ & AAS & - & - \\
\hline & $\mathrm{C}_{2}$ & $(\mathrm{Hg})$ & $\mathrm{mg} / \mathrm{L}$ & AAS & - & - \\
\hline & $\mathrm{C}_{3}$ & $(\mathrm{Hg})$ & $\mathrm{mg} / \mathrm{L}$ & AAS & - & - \\
\hline
\end{tabular}

Source: Bandar Lampung Standardization Research Center

The average value of mercury $(\mathrm{Hg})$ concentration in plants can be seen from Table 5.

Table 5. Average Concentration of Mercury ( $\mathrm{Hg})$ in Plants

\begin{tabular}{|l|l|c|}
\hline No. & \multicolumn{1}{|c|}{ Plants } & Average Concentration (Hg) in Plants \\
\hline 1. & Rat Purun & 2.173 \\
\hline 2. & Water hyacinth & 2.146 \\
\hline 3. & No plant & - \\
\hline
\end{tabular}

Source : Primer Data

$$
\bar{x}=\frac{x 1+x 2+\cdots+x n}{n}
$$

Example :

\section{Rat Purun Plants}

Average $=\frac{\mathrm{A}_{1}+\mathrm{A}_{3}}{2}$

$$
=\frac{2.216 \mathrm{mg} / \mathrm{L}+2.130 \mathrm{mg} / \mathrm{L}}{2}=2.173 \mathrm{mg} / \mathrm{L}
$$

Average decline: 2.173 


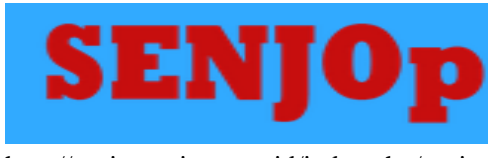

http://senjop.ppj.unp.ac.id/index.php/senjop
Science and Environmental Journals for Postgraduate

Vol. 2 No. 1 (pp. 1-11) December 2019

p ISSN 2655-5085

e_ISSN 2655-5239

From the calculation of the average value, it is possible that there are data that do not participate calculated like A2 data. A2 repetition data, having values far from A1 and A3 values, are eliminated for calculations. From Table 4.5 can be calculated the efficiency of absorption of mercury $(\mathrm{Hg})$ by plants. Mercury absorption efficiency $(\mathrm{Hg})$ is presented in Table 6.

Table 6. Efficiency of Mercury (Hg) Absorption by Plants

\begin{tabular}{|l|l|c|}
\hline No. & \multicolumn{1}{|c|}{ Plants } & Eficiency (\%) \\
\hline 1. & Rat Purun & $97.88 \%$ \\
\hline 2. & Water hyacinth & $96.66 \%$ \\
\hline 3. & No plant & - \\
\hline
\end{tabular}

Source : Primer Data

Example :

$$
\text { Eff }=\frac{C_{\text {akhir }}-C_{\text {awal }}}{C_{\text {awal tanaman }}} \times 100 \%
$$

Rat Purun

$$
\begin{aligned}
\text { Eff } & =\frac{2.173-0}{2.22} \times 100 \% \\
& =97.88 \%
\end{aligned}
$$

The efficiency of $\mathrm{Hg}$ absorption by rat purun plants (Eleochalis dulcis) and water hyacinth (Elchhornia crassipes) were $97.88 \%$ and $96.66 \%$, respectively, with the efficiency of decreasing (loss) $\mathrm{Hg}$ in wastewater (Table 4.3) for rat purses (Eleochalis dulcis) and water hyacinth (Elchhornia crassipes) this shows that the decrease (loss) of $\mathrm{Hg}$ in liquid waste, all absorbed by rat purun plants (Eleochalis dulcis) or water hyacinth (Elchhornia crassipes). There is no $\mathrm{Hg}$ in evaporated liquid waste. This is in accordance with the nature of $\mathrm{Hg}$ which is difficult to evaporate at ambient temperature. Measurement of Water Acidity $(\mathrm{pH})$. Measuring the acidity of water $(\mathrm{pH})$ is carried out on the first day and day 15 . The degree of acidity in the three treatments can be seen in Table 7 .

Table 7. Measurement of Acidity $(\mathrm{pH})$ in Mercury Wastewater $(\mathrm{Hg})$

\begin{tabular}{|l|l|c|c|}
\hline \multirow{2}{*}{ No. } & \multicolumn{1}{|c|}{ Plants } & \multicolumn{2}{|c|}{ Acidity (pH) Concentration } \\
\cline { 3 - 4 } & & Start & End \\
\hline 1. & Rat Purun & 5.7 & 6.5 \\
\hline 2. & Water hyacinth & 5.7 & 6 \\
\hline 3. & No plant & 5.9 & 5.8 \\
\hline
\end{tabular}

Source: Primer Data, 2015 


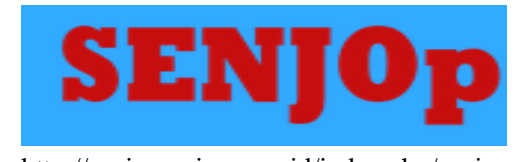

http://senjop.ppj.unp.ac.id/index.php/senjop
Science and Environmental Journals for Postgraduate

Vol. 2 No. 1 (pp. 1-11) December 2019

p_ISSN 2655-5085

e_ISSN 2655-5239

From the table above, it can be seen on the first day that the $\mathrm{pH}$ conditions are still below neutral $(\leq 5.8)$ for each treatment. $\mathrm{pH}$ rises to near neutral $(7)$ on day 15 . The increase in $\mathrm{pH}$ is caused by photosynthesis, denitification, organic nitrogen breakdown and sulfate reduction (Haryati, 2012 in Natalina, 2013). Photosynthesis is a physiological property possessed by plants. The increase in $\mathrm{pH}$ is due to photosynthesis from plants where $\mathrm{CO} 2$ will be reduced to carbohydrate. Decreasing the amount of free $\mathrm{CO} 2$ in wastewater has a correlation with increasing pH (Suardana, 2005 in Natalina, 2013).

The decrease in $\mathrm{pH}$ and resistance to the nitrification process showed a positive correlation with the growth of rat purun (Mulyani, 2005 in Belami, 2013). These results indicate that the acidity level in wastewater that is not too high affects the presence of mercury contained in wastewater. According to (Palar, 1994 in Belami, 2013), low water $\mathrm{pH}$ will cause mercury in the waters to be stable, whereas if the water $\mathrm{pH}$ is high it can reduce the solubility of metals in water. The increase in $\mathrm{pH}$ can change the stability of mercury from a form that is easily absorbed by plants and becomes difficult to absorb by plants by forming bonds with particles in the water that will settle.

\section{Temperature Measurement of Water}

During the phytoremediation treatment measurements were also made on the temperature present in liquid waste. The results of temperature measurements during the treatment took place ranging from $260 \mathrm{C}$ to $270 \mathrm{C}$. The main factor capable of influencing temperature changes in liquid waste is the intensity of light received by water and room temperature. The water temperature during the treatment did not cause a change in mercury levels during the treatment, because the light intensity regarding liquid waste during treatment was not too large. This is also evident from the control wastewater without plants showing no change in mercury levels $(\mathrm{Hg})$ from day 0 to day 15 with the existing temperature. According to (Stwertka, 1998 in Belami et al., 2014) Hg will boil and evaporate at $3570 \mathrm{C}$, in other words the temperature in this study is the normal temperature for $\mathrm{Hg}$, ie $\mathrm{Hg}$ is still in a liquid condition. 


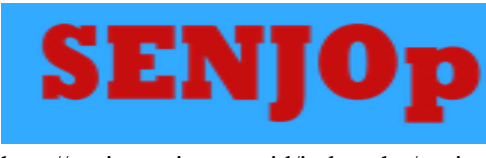

http://senjop.ppj.unp.ac.id/index.php/senjop
Science and Environmental Journals for Postgraduate

Vol. 2 No. 1 (pp. 1-11) December 2019

p_ISSN 2655-5085

e_ISSN 2655-5239

\section{Visual Observation of Plants}

Direct observations made with the aim to see the physical changes that occur in plants which are indicators in the phytoremediation method on mercury waste $(\mathrm{Hg})$, visual observations of plants can be seen in Table 8 .

Table 8. Direct Observations of Plant Conditions in Research

\begin{tabular}{|l|l|l|l|}
\hline No. & Day & \multicolumn{2}{|c|}{ Plant Parameters Observed } \\
\cline { 3 - 5 } & $0-7$ & $\begin{array}{l}\text { Ro changes in plants from day 0 to day 7, } \\
\text { the condition of the plants is still good. }\end{array}$ & $\begin{array}{l}\text { No changes in plants from day 0 to day 7, } \\
\text { the condition of the plants is still good }\end{array}$ \\
\hline 1. & $8-10$ & $\begin{array}{l}\text { It has begun to appear small yellow spots } \\
\text { on old leaves. }\end{array}$ & $\begin{array}{l}\text { Experiencing changes in leaves and stems } \\
\text { with more yellow spots than rat puruns. }\end{array}$ \\
\hline 3. & $11-13$ & $\begin{array}{l}\text { Experiencing changes in the old stems, } \\
\text { with brown stems with yellow spots. }\end{array}$ & $\begin{array}{l}\text { Old plants have undergone changes in dead } \\
\text { leaves and some are yellowish in color. }\end{array}$ \\
\hline 4. & $14-15$ & $\begin{array}{l}\text { Old leaves and stems undergo changes } \\
\text { that are partially dead and withered. } \\
\text { However, plants that are still alive are seen } \\
\text { from the presence of new shoots in plants. }\end{array}$ & $\begin{array}{l}\text { Old leaves and stems undergo changes, } \\
\text { namely wilting, and some die, so that the } \\
\text { water experiences odor, which is caused by } \\
\text { decay in dead leaves. }\end{array}$ \\
\hline
\end{tabular}

Source : Primer Data

Direct observations were intended to see the condition of rat purun plants (Eleochalis dulcis) and water hyacinth (Elchhornia crassipes) during the phytoremediation process. From day 8, rat purun plants (Eleochalis dulcis) and water hyacinth (Elchhornia crassipes) undergo changes in the leaves with characteristics that begin to wither and the presence of yellow spots. Within 15 days the plants were still alive even though some had withered. Mercury absorbed by plants has an effect on plants, including shoots and plant roots will dry up, chlorophyll content in leaves decreases, protein content will also decrease, and the concentration of $\mathrm{Ca}$ and $\mathrm{K}$ in plant tissues will decrease, (Azad and Kafilzadeh, 2012 )

\section{CONCLUSION}

The conclusions obtained from this study are: (1) Rat Purun (Eleochalis dulcis) and water hyacinth (Elchhornia crassipes) can be used to reduce $\mathrm{Hg}$ content by phytoremediation method. This is indicated by the efficiency of decreasing the $\mathrm{Hg}$ content of $97.88 \%$ for rat purun (Eleochalis dulcis) and $96.66 \%$ for water hyacinth (Elchhornia crassipes), (2) Efficiency in decreasing rat purun plants (Eleochalis dulcis) is better than that of water hyacinth plants (Elchhornia crassipes), this is due to rat purun plants 


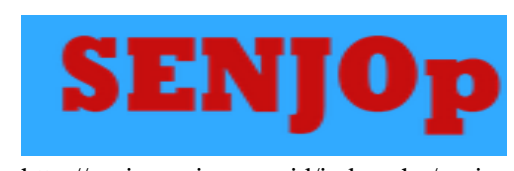

http://senjop.ppj.unp.ac.id/index.php/senjop
Science and Environmental Journals for Postgraduate

Vol. 2 No. 1 (pp. 1-11) December 2019

p ISSN 2655-5085

e_ISSN 2655-5239

(Eleochalis dulcis) having a large root cavity (cortek) which causes the absorption process to be faster compared to water hyacinth (Elchhornia crassipes), (3) The $\mathrm{pH}$ of wastewater in the treatment using rat purun (Eleochalis Dulcis) and water hyacinth (Elchhornia crassipes) increased to near normal $\mathrm{pH}$ during the phytoremediation process. This is caused by the process of phytosynthesis, denitification, and (4) Plants begin to change on the 9th day of water hyacinth (Elchhornia crassipes) and day 11 in rat purun (Eleochalis dulcis), with the appearance of yellow spots on the leaves and stems of plants.

\section{REFERENCES}

Agustina, L. 2004. Dasar Nutrisi Tanaman. Rineka Cipta. Jakarta.

Arisandi, P. 2001. Mangrove Jenis Apiapi (Avicennia marina) Alternatif Pengendalian Pencemaran Logam Berat Pesisir, Lembaga Kajian Ekologi dan Konservasi Lahan Basah. http://tech.group.yahoo.com/burung pemangsa_Indonesia. (diakses 18 juni 2015).

Asikin, S. dan Thamrin, M. 2012. Manfaat Purun Tikus (Eleocharis Dulcis) Pada Ekosistem Sawah Rawa. Jurnal Litbang Pertanian.

Aulia Nurmitha. A. 2013. Fitoremediasi Pengolahan Limbah Cair Rumah Tangga Dengan Memanfaatkan Water hyacinth. Jurnal, Universitas Hasanuddin. 